\title{
Gambaran Pelayanan Konseling Gizi pada Pasien Diabetes Mellitus Tipe 2 di Puskesmas Jatinangor Tahun 2015
}

\author{
Puteri Fadillah Zahra, ${ }^{1}$ Dewi Marhaeni Diah Herawati, ${ }^{2}$ Miftahurachman, ${ }^{3}$
}

${ }^{1}$ Fakultas Kedokteran Universitas Padjadjaran,

${ }^{2}$ Departmen Ilmu Kesehatan Masyarakat, Fakultas Kedokteran, Universitas Padjadjaran,

${ }^{3}$ Departmen Ilmu Penyakit Dalam, Fakultas Kedokteran, Universitas Padjadjaran/Rumah Sakit Umum

Pendidikan Hasan Sadikin, Bandung, Indonesia

\begin{abstract}
Abstrak
Terapi konseling gizi oleh tenaga puskesmas sangat diperlukan untuk pasien DM tipe 2, berfungsi mengontrol diet pasien agar tidak timbul masalah yang lebih kompleks. Pelayanan konseling gizi di puskesmas saat ini, diduga masih belum dilakukan secara optimal. Penelitian dilakukan untuk mengetahui gambaran pelayanan konseling gizi pada pasien DM tipe 2 di Puskesmas Jatinangor. Desain penelitian adalah deskriptif kualitatif dengan strategi studi kasus, pengambilan data dilakukan melalui wawancara mendalam dan observasi. Jumlah responden terdiri dari 1 nutrisionis, 1 dokter dan 3 pasien. Penelitian dilakukan pada bulan Agustus-November 2015. Analisis data dilakukan secara konten analisis. Tahapan proses konseling gizi berjalan sesuai dengan standar yang ditetapkan oleh Kemenkes. Konseling yang dilakukan masih menggunakan metode yang konvensional. Hambatan yang dialami petugas Puskesmas adalah dalam melakukan monitoring dan evaluasi hasil konseling. Hal ini disebabkan karena pasien yang melakukan kunjungan ulang masih rendah, selain itu fasilitas puskesmas terbatas seperti ruang konseling gizi dan food model. Pelayanan konseling gizi di puskesmas belum berjalan dengan baik, metode konseling yang digunakan masih konvensional serta belum didukung fasilitas yang memadai. Perlu peningkatan kapasitas tenaga dalam melakukan konseling dengan pendekatan yang tepat serta pengadaan ruangan konseling dan food model.
\end{abstract}

Kata Kunci: Diabetes Mellitus tipe 2, konseling gizi, puskesmas.

\section{Nutrition Counseling Services in Patients with Type 2 Diabetes Mellitus at Jatinangor Public Health Centerin 2015}

\begin{abstract}
Medical nutrition therapy by health workers is required in patients with type 2 diabetes mellitus to control the patient's diet blood sugar levels to avoid worsening complex symptoms. Nutritional counseling in public health center, assumption is still not optimal. This study was conducted to determine the picture of nutrition counseling in patient's with type 2 diabetes mellitus in Jatinangor public health center. Research design was descriptive qualitative with case study strategyc, data collection was conductedindepth interview and observation. The number of respondent was 1 nutritionist, one physician and three patients. The study was conducted at Agustus until December. Data analysis was conducted content analysis. Nutritional counseling process was run in accordance with the standards established by the Ministry of Health. Counseling was done still using conventional method. Barriers experienced health worker is in its monitoring and evaluation of the results of counseling. This is because patient who do repeat visits are still low, lack of nutritional counseling room and food models. Nutrition counseling services in health centers was not run well, counseling methods used are conventional and have not been supported by adequate facilities. Need to increase of capacity in counseling with the right approach and the provision of counseling room and food models.
\end{abstract}

Keywords: Nutrition counseling, public health center, type 2 diabetes mellitus.

Korespondensi:

Puteri Fadillah Zahra

Fakultas Kedokteran Universitas Padjadjaran

Jl. Prof. Dr. Eyckman No. 38 Bandung 40161

Mobile : 082315026869

Email :puteri.fadillah08@yahoo.com 


\section{Pendahuluan}

Diabetes mellitus (DM) didefinisikan sebagai penyakit kronis yang merupakan hasil dari kurangnya insulin yang disekresikan oleh pankreas atau tidak efektifnya tubuh dalam penggunaan hormon insulin tersebut. World Health Organization (WHO) memprediksikan bahwa akan terdapat kenaikan jumlah penderita diabetes dari 135 juta pada tahun 1995 hingga 300 juta pada tahun 2025. Peningkatan yang paling tinggi diprediksikan akan terjadi di Benua Asia. ${ }^{1}$

Hasil survei yang dilakukan oleh WHO menunjukkan bahwa Indonesia menempati urutan ke-4 terbesar dalam jumlah penderita DM setelah India, Cina dan Amerika Serikat dengan pravalensi $8,6 \%$ dari total penduduk. Temuan tersebut membuktikan bahwa penyakit DM merupakan masalah kesehatan yang sangat serius, hal tersebut didukung dengan tingginya prevalensi prediabetes di Indonesia., ${ }^{2,3}$

Penyakit DM secara umum memiliki 2 tipe, yaitu DM tipe 1 dan DM tipe 2, dimana penyakit DM tipe 2 merupakan kasus yang paling banyak dijumpai. Salah satu faktor penyebab tingginya prevalensi penyakit DM tipe 2 adalah pola makan yang tidak sehat, meliputi asupan tinggi karbohidrat dan lemak, kebiasaan mengkonsumsi makanan siap saji dengan kandungan natrium tinggi, dan konsumsi makanan rendah serat. ${ }^{4}$ Penatalaksanaan penyakit DM, selain pemberian obat adalah dengan diet sehat dan komposisi makanan yang seimbang serta anjuran untuk berolah raga secara rutin. ${ }^{5}$

Penanganan penyakit DM secara umum memiliki 6 pondasi yaitu pemberian edukasi, terapi gizi, aktivitas fisik, penanggulangan konsumsi rokok, penanganan psikososial dan imunisasi. Status gizi pasien sangat berpengaruh pada proses penyembuhan penyakit, sehingga memerlukan terapi gizi medis untuk penyembuhannya. ${ }^{6}$ Oleh karena itu, selama proses penanganan penyakit DM maka petugas puskesmas harus melakukan penilaian status gizi agar rekomendasi nutrisi dapat dilakukan dengan tepat.

Puskesmas merupakan fasilitas pelayanan kesehatan yang menyelenggarakan upaya kesehatan masyarakat dan upaya kesehatan perorangan tingkat pertama. Pukesmas memiliki tenaga dan pelayanan khusus dalam bidang gizi. Salah satu tugas pokok dan fungsi petugas gizi di puskesmas adalah memberikan edukasi gizi baik dalam bentuk konseling maupun penyuluhan pada pasien yang datang berkunjung ke puskesmas maupun pada kelompok masyarakat. Program konseling gizi di Puskesmas Jatinangor merupakan salah satu program dalam pelayanan gizi kepada pasien yang berkunjung di puskesmas. Hal tersebut dilakukan dalam memenuhi tugas sebagai pelayanan kesehatan primer terutama dalam pemberian terapi gizi medis (TGM) pada pasien DM. Rendahnya kunjungan ulang yang dilakukan pasien DM merupakan salah satu masalah yang dialami petugas gizi dalam melakukan monitoring dan evaluasi terhadap hasil konseling dan keberhasilan terapi diet pasien. Penelitian bertujuan untuk melakukan kajian terhadap pelayanan konseling gizi pada pasien DM tipe 2 di Puskesmas Jatinangor. Ruang lingkup penelitian adalah melakukan pengkajian dari sisi input dan proses pelayanan konseling gizi di puskesmas.

\section{Metode}

Desain penelitian adalah deskriptif kualitatif dengan strategi studi kasus. Pengambilan sampel penelitian dilakukan secara purposive sampling. Kriteria inklusi meliputi pasien yang terdiagnosis DM tipe 2 yang tercatat berkunjung di Puskesmas Jatinangor, sudah melakukan konseling gizi, memiliki alamat lengkap, dapat berkomunikasi dengan baik dan bersedia ikut serta dalam penelitian. Kriteria eksklusi pasien memiliki gangguan jiwa, kognisi, pendengaran serta gangguan dalam berbicara, berdasarkan hasil diagnosis dokter yang berada pada kartu status pasien. Jumlah subyek penelitian ada 5 orang, meliputi 1 orang dokter, 1 orang nutritionis dan 3 orang pasien. Pengambilan data dilakukan melalui wawancara mendalam dan observasi saat proses konseling dilakukan oleh petugas puskesmas. Uji validitas dan reabilitas dilakukan trustworthiness meliputi credibility, transferability, dependability dan confirmability. Penelitian dilakukan pada bulan Agustus sampai dengan November 2015. Penelitian ini telah mendapat ethical clearance dari Komite Etik FK Unpad pada tanggal 27 Agustus 2015 dan telah memenuhi 4 aspek etik yaitu respect for person, beneficence, maleficence dan justice

\section{Hasil}

Wawancara dilakukan pada 3 orang pasien DM tipe 2, kemudian dilakukan triangulasi pada 1 dokter umum serta 1 nutrisionis. Wawancara dilakukan di puskesmas dan di rumah pasien. Peneliti melakukan observasi terhadap proses konseling gizi yang dilakukan di Puskesmas Jatinangor selama 3 hari.

Tahapan proses konseling pada pasien DM tipe 2 yang datang ke puskesmas adalah sebagai berikut, setelah ke bagian pendaftaran, pasien masuk ke ruang pengobatan dan dokter 
melakukan pemeriksaan fisik seperti pengukuran tensi dan keadaan umum pasien serta pengukuran tinggi badan dan berat badan. Selain itu dokter juga melakukan tanya jawab tentang keluhan dan apa yang dirasakan pasien. Setelah itu, pasien diminta untuk periksa ke laboratorium untuk kontrol kadar gula darahnya. Hasilnya dikonsulkan ke dokter, setelah itu pasien diminta konsultasi ke bagian gizi puskesmas. Adapun hasil wawancaranya adalah sebagai berikut :

"...udah daftar langsung ke dokter bagian pemeriksaan, ditensi dulu terus diperiksa apa yang sakit di luar sebelum dokter. Terus ditimbang sama tinggi badan, terus masuk ke dokter, diperiksa sama dokter, terus ditulis. Terus sama dokter ditanya, bu apa yang sakit? Ini kesemutan, ini sakit-sakit, terus di dalem ditanya, punggung sakit? Iya sakit terus ini punuk juga sakit? Iya sakit, terus ini nya (perutnya) sakit? Iya sakit tembusnya sampe ke belakang, gitu.. Bu ini mah harus di lab, da emang ibu juga mau dilab. Terus masuk ke kamar 4 ke lab, udah di lab ke dokter lagi baru masuk ke ibu yuli gizi..." (Responden 03)

Hasil wawancara tersebut tidak jauh berbeda dengan hasil observasi yang dilakukan di puskesmas. Dibawah ini adalah tahapan proses konseling pasien DM tipe 2 di Puskesmas Jatinangor. Berdasarkan hasil wawancara dan observasi diperoleh tema dalam tahapan proses konseling adalah sebagai berikut :

Pembangunan dasar-dasar konseling gizi; Dasar-dasar yang dibangun saat awal melakukan konseling gizi berupa perkenalan, permintaan surat rujukan dan penjabaran tujuan. Berdasarkan observasi yang dilakukan di Puskesmas Jatinangor, ketiga tahap ini sudah dilakukan. Penilaian yang dilakukan untuk mengevaluasi pembangunan dasar-dasar konseling gizi dari segi prespektif nutritionis. Hal tersebut digunakan untuk menanyakan apakah nutrisionis menjabarkan tujuan sebelum memulai konseling gizi.

Wawancara juga dilakukan pada pasien, hal tersebut digunakan untuk melakukan triangulasi terhadap jawaban nutritionis tentang penjabaran tujuan pentingnya konseling serta menanyakan pentingnya konseling gizi bagi pasien. Ketiga pasien menyatakan bahwa dokter dan nutrisonis di Puskesmas Jatinangor menjabarkan tujuan pentingnya konseling gizi, tetapi ketika ditanya tujuan dan pentingnya konseling gizi diperlukan pada pasien DM tipe 2, ketiga pasien memiliki pendapat yang bervariasi, meskipun pada intinya mereka ingin menjadi sehat kembali. Ada pasien yang berpendapat untuk menambah pengetahuan tentang makanan, sehingga tahu bagaimana melakukan diet yang baik untuk mereka. Namun, ada pasien yang berpendapat bahwa mereka ingin sehat dan tidak mau terkena penyakit karena tidak ada manfaatnya bagi diri pasien.

Pengkajian gizi; Pengkajian gizi yang dilakukan dalam tahap konseling adalah berupa pengukuran antropometri, tes laboratorium, identifikasi gejala klinis dan identifikasi riwayat makan dengan metode food recall. Berdasarkan hasil wawancara sebelum dilakukan pengkajian dilakukan perkenalan terlebih dahulu, kemudian petugas menghitung tinggi badan dan berat badan pasien sehingga diperoleh status gizi pasien, juga

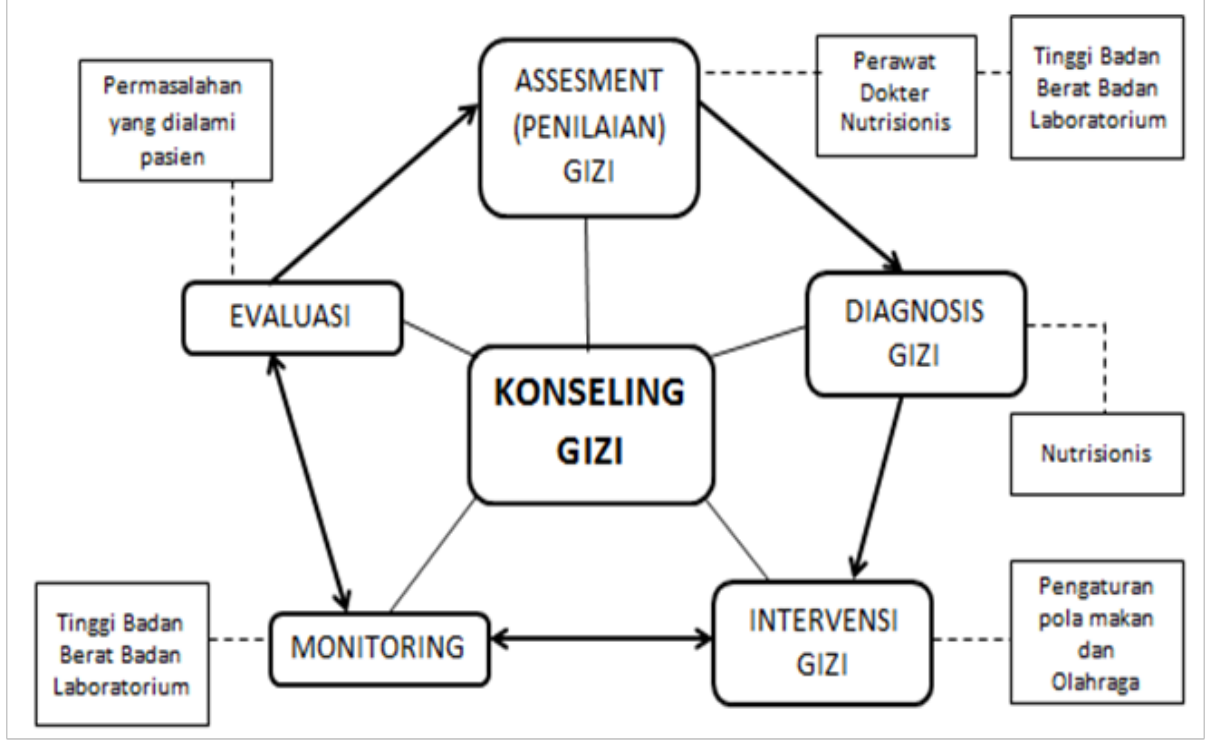

Gambar 1 Tahapan proses konseling gizi di Puskesmas Jatinangor 
dihitung aktivitas fisik pasien, setelah itu petugas menggali riwayat makan pasien. Hal tersebut sesuai dengan hasil observasi yang dilakukan oleh peneliti, pengukuran antropometri dilakukan sebelum memasuki ruang pemeriksaan dokter dengan melakukan pegukuran tinggi badan dan berat badan. Adapun tujuannya adalah untuk menghitung berat badan ideal pasien dan status gizi pasien. Selain itu juga dilakukan pengkajian riwayat makan melalui metode food recall selama 24 jam ke belakang. Berdasarkan hasil observasi selain melakukan pengukuran antropometri petugas juga melakukan pengkajian gizi melalui tes laboratorium kadar gula darah sewaktu atau kadar glukosa darah puasa, sesuai dengan permintaan dokter.

Diagnosis gizi; Sebelum memulai intervensi gizi, ada beberapa hal yang harus dipertimbangkan terkait dengan penyakit penyerta. Tahap ini merupakan tahap diagnosis gizi. Berdasarkan hasil observasi dan wawancara, diagnosis gizi yang dilakukan oleh nutrisionis berupa pertanyaan kebiasaan makan sehari-hari, alergi makanan, serta riwayat penyakit yang dimilikinya seperti kolesterol, asam urat dan hipertensi. Pada tahap penetapan diagnosis gizi, petugas gizi juga selalu menanyakan tentang pekerjaan responden dan kemampuan ekonomi. Hal ini penting untuk mengetahui faktor determinan yang mungkin menjadi penyebab kejadian penyakit tersebut, sehingga dapat digunakan untuk melakukan penyesuaian pemilihan makanan saat dilakukan edukasi intervensi gizi kepada pasien.

“...di samping itu juga kita melihat kebiasaan makannya seperti apa termasuk ada alergi makanan atau tidak, terus faktor ekonomi kita melihat yaa biasanya. Sampai kerjanya dimana"(Responden 01)

Intervensi gizi; Intervensi gizi merupakan tahap konseling yang dilakukan oleh nutrisonis Puskesmas Jatinangor berupa pengaturan asupan makan sehari-hari yang disesuaikan dengan berat badan ideal. Berat badan ideal sudah di hitung pada tahap pengkajian gizi. Perhitungan tersebut disesuaikan berdasarkan berat badan, tinggi badan serta jenis kelamin pasien. Kebutuhan energi basal untuk pria $30 \mathrm{kkal} / \mathrm{kg} \mathrm{BB}$, sedangkan untuk wanita $25 \mathrm{kkal} / \mathrm{kg} \mathrm{BB}$ perhari. Konseling gizi yang diberikan kepada pasien masih konvensional, belum menggunakan teknik atau pendekatan dengan teori tertentu, dimana petugas gizi hanya memberikan informasi tentang diet makanan yang tepat untuk pasien.

Program diet yang dianjurkan oleh nutrisionis berpacu pada brosur diet khusus pasien DM. Terdapat 2 brosur yang diberikan kepada pasien, brosur tersebut meliputi brosur anjuran makan khusus untuk pasien DM dan brosur makanan pengganti. Pada brosur anjuran makan diisi sesuai kebiasaan makan sehari-hari disertai dengan takaran yang berlaku dengan menggunakan satuan gram dan satuan alat ukur rumah tangga seperti contohnya menggunakan gelas.

"iya jadi misalkan kita sudah menyusun ya... disini sebenernya ada ukuran berat dalam gram, kalo di rumah ada timbangan boleh pake timbangan. Kalo ngga ada boleh pake ukuran rumah tangga, pakai gelas. Jadi kita pakai ukuran rumah tangga juga bisa. Misalkan nasi 100 gram sama dengan tiga perempat gelas..."(Responden 01)

Edukasi pengaturan makanan yang disampaikan oleh nutrisionis pada pasien DM tipe 2, selain berupa takaran yang berlaku, disampaikan pula jenis-jenis makanan yang diperbolehkan serta jenis-jenis makanan yang dilarang sesuai yang tertulis di brosur makanan. Hasil wawancara yang ditujukan kepada pasien DM tipe 2 mengenai program diet yang dianjurkan oleh nutrisionis Puskesmas Jatinangor menunjukan bahwa beberapa pasien secara umum telah memahami tentang pengaturan gizi yang tepat khususnya bagi pasien DM.

Beberapa pasien DM tipe 2 dapat menjelaskan program diet secara lengkap sambil menunjukan brosur makanan yang diberikan oleh nutrisionis saat pertemuan pertama berlangsung, sedangkan beberapa pasin lain belum terlalu paham mengenai diet yang harus dilakukannya. Pasien yang paham tentang diet yang harus dilakukannya bercerita bahwa makanan yang boleh dikonsumsi adalah makan nasi 3/4 gelas karena tidak boleh lebih dari 2 ons, mengurangi makanan manis, perbanyak makan buah yang banyak mengandung serat, harus mengurangi buah yang memiliki energi tinggi, perbanyak makan sayur, makan protein baik berasal dari nabati seperti tahu dan tempe dan protein hewani seperti telur tetapi hanya boleh putihnya saja sedangkan kuningnya dilarang dimakan.

Selain itu minyak yang digunakan untuk menggoreng harus menggunakan minyak jagung, responden juga harus mengurangi kolesterol dan lemak. Meskipun nutritionis telah melakukan edukasi dan membuat leaflet untuk pengaturan makan pasien diabetes mellitus, namun ternyata belum seluruh pasien dapat memahami dengan baik tentang diet yang harus dijalani dan dilakukan oleh pasien. Program diet nampaknya belum dijalankan dengan baik oleh pasien, ada pasien yang mampu menjalankan program diet sesuai brosur dan yang disarankan oleh nutrisionis, namun ada pasien menjalani diet tanpa patokan brosur makanan, tetapi tetap membatasi jumlah makanan yang manis. Pemahaman pasien terhadap diet yang tepat masih belum optimal, 
seperti makanan sayuran wortel harus dibatasi karena manis. Beberapa pasien masih belum mengerti tentang karbohidrat sumber, mereka mengira bahwa ketela pohon dan ubi bukan merupakan karbohidrat, sehingga kedua jenis makanan tersebut menjadi camilan mereka.

“..sop juga gaboleh kan buat diabet wortelnya gaboleh, makannya di gram-gram juga.. Ya ibu juga dulu makan mah ya sekenyangnya aja. Tapi sekarang mah udah ngga, kayak nasi dibatesin, didinginin dulu baru dimakan terus makan secukupnya..."(Responden 03) "Ah sekarang mah kurang, setengah sukil paling nasinya. Ada tahu di goreng, terus kalau ada ketela pohon, ubi ya gitu gitu we... Da suami juga suka bilang awas jangan ngemil terus gitu"(Responden 04)

Selain pengaturan diet, olahraga juga merupakan hal yang penting dalam proses intervensi gizi khususnya untuk pasien DM. Selama proses konseling gizi berlangsung, baik dokter maupun nutrisionis keduanya senantiasa mengingatkan pasiennya untuk melakukan olahraga secara berkala. Ketiga pasien yang sudah diwawancarai menjalani kegiatan olahraga secara rutin. Saran yang diberikan nutritionis pada pasien yang sudah tua dan terkena penyakit diabetes mellitus adalah pasien cukup olah raga dengan melakukan jalan kaki setiap hari minimal 10 menit adan diharapkan pasien dapat menjalankan aktivitas sehari-hari seperti menyapu dan mengepel atau membersihkan rumah. Pasien yang usianya relativ lebih muda melakukan aktivitas olah raga dengan lari di tempat sampai keluar keringat, namun ada juga yang lari seminggu $3 x$ sekitar 30 menit - 60 menit, mengikuti senam jantung serta ada yang jalan kaki ke pasar. Kegiatan ke pasar menjadi kegiatan rutin dilakukan setiap hari, sekaliyan olah raga dan pulangnya bisa bawa sayuran seperti hasil wawancara dibawah ini.

"ibu mah tiap pagi bangun jam 6 beres beres langsung ke pinggir jalan cibeusi terus ke pasar pulang pulang bawa sayuran. Ya jalan-jalan, ah 2 jam paling jalan-jalan ke luar, sama ibu-ibu sini.."(Responden 05)

Monitoring dan evaluasi; Monitoring dan evaluasi intervensi gizi hanya bisa dilakukan ketika pasien melakukan kunjungan ulang. Hal ini merupakan hambatan yang dimiliki program konseling gizi di Puskesmas Jatinangor dikarenakan pasien yang sudah melakukan konseling gizi pertama melakukan kunjungan ulang hanya ingin mengecek kembali gula darah. Ketika gula darah tetap tinggi dan dirujuk lagi untuk melakukan konseling gizi rata-rata pasien menolak.

"Kalau misalkan ternyata gak ada perbaikan biasanya sih dirujuk ke gizi lagi tapi rata- rata semua gamau.. Jadi ya 'aah atos ah dok ah, da tos apal, tos terang' gitu. Mereka alasannya gitu, gamau. Jadi mereka pengennya dengan obat langsung sembuh"(Responden 02)

Beberapa pasien mengaku belum melakukan kunjungan ulang dikarenakan baru berobat ke puskesmas kurang dari sebulan, sedangkan untuk pasien lain sudah melakukan kunjungan ulang untuk kontrol sebanyak $3 \mathrm{x}$ tetapi berhenti 3 bulan yang lalu dikarenakan sudah merasa sehat. Bentuk monitoring dan evaluasi untuk menilai keberhasilan dari program diet secara objektif hanya dilihat berdasarkan antropometri dan tes laboratorium gula darah sewaktu atau gula darah puasa.

"...biasanya yang ke sini langsung diukur lagi ya. Antropometri sama hasil labnya, gula darah"(Responden 01)

Mengakhiri konseling gizi; Akhir dari tahap pelaksanaan konseling gizi berupa sesi pertanyaan (diskusi) dan penjadwalan kunjungan ulang. Berdasarkan hasil observasi, selama proses konseling berlangsung rata-rata pasien bertanya di tengah-tengah penjelasan intervensi gizi yang menghasilkan diskusi yang aktif selama konseling. Meskipun demikian, nutrisionis senantiasa pula mempersilahkan pasien untuk bertanya di akhir konseling dan mengingatkan kembali untuk melakukan kunjungan ulang sebulan ke depan.

Berdasarkan hasil wawancara dan observasi, fasilitas yang dimiliki di Puskesmas Jatinangor tergolong kurang, dikarenakan tidak adanya food model dan ruangan khusus untuk melakukan konseling. Hal ini juga diakui oleh nutrisionis yang menjadi salah satu hambatan yang dialami saat melakukan proses konseling gizi.

"Paling yang pertama ya fasilitas food model. Udah minta sih ya. Katanya dulu pernah dikirim tapi ga ada....., yaa sudah diajukan sebetulnya yah.. Terus kita belum sampai ke pemantauan yang memang betul-netul intensif. Kadang kalo udah sekali periksa yaa udah gitu aja.. sama ya pengennya ada runagan khusus juga sih hehe"(Responden 01).

Selain sarana dan prasarana pendukung kegiatan konseling seperti ruang konseling dan food model petugas nutrisionis juga membutuhkan medical record untuk data pasien yang lengkap seperti nomor telefon dan alamat yang jelas serta catatan hasil evaluasi setiap pasien datang berkunjung, agar dapat dilakukan monitor terus menerus terhadap upaya-upaya yang telah dilakukan baik oleh pasien, keluarga pasien serta pihak puskesmas. 


\section{Pembahasan}

Tahapan proses konseling gizi di Puskesmas Jatinangor secara umum sudah berjalan sesuai dengan pedoman penatalaksanaan gizi yang ditetapkan oleh Menteri Kesehatan Republik Indonesia untuk pelayanan gizi di rumah sakit. Kemenkes belum membuat peraturan tentang pelayanan gizi di pelayanan primer seperti puskesmas, hal tersebut penting sekali dibuat oleh Kemenkes karena terapi gizi bukan hanya sekedar menjadi pendukung dalam pengobatan pasien tetapi juga menjadi terapi penting bagi pasien terutama pada pasien DM tipe 2. Konseling gizi yang berjalan di Puskesmas Jatinangor masih menggunakan metode konvensional dimana penyampaiannya hanya sebatas pengaturan makan, belum mempertimbangkan permasalahan-permasalahan yang dialami pasien secara detil seperti kondisi psikis pasien, riwayat keluarga, ekonomi serta kehidupan sosial pasien.

Metode konseling yang dilakukan oleh petugas gizi puskesmas belum menggunakan pendekatan yang efektif untuk mengubah perilaku seseorang seperti Health Belief Model (HBM), Transtheoritical Model(TTM) dan Theory of Plan Behavior (TPB) dll. Berbagai penelitian mencantumkan bahwa edukasi gizi yang efektif memiliki pengaruh yang baik terhadap hasil klinis serta kualitas hidup pasien. ${ }^{9}$ Hal-hal tersebut menunjukan bahwa pengaruh konseling gizi merupakan pengaruh yang besar dalam manajemen pengobatan pasien. Hanya saja, penyampaian konseling gizi di pelayanan kesehatan primer masih menggunakan teknik konvensional sehingga menjadi masalah yang perlu mendapat perhatian khusus.

Pemberian konseling gizi tidak cukup hanya dengan menyampaikan jenis makanan apa saja yang harus dikurangi serta olah raga yang cukup, tetapi juga harus mampu mengubah perilaku pasien tentang gaya hidup. Dalam mengubah kebiasaan pola makan pasien tentunya berkaitan dengan mengubah perilaku, pola hidup serta kehidupan sosial pasien. ${ }^{10}$ Penelitian yang dilakukan oleh Gravel, Legare dan Graham serta Jansink dkk menyatakan bahwa sangatlah sulit bagi tenaga kesehatan primer dalam memotivasi pasien untuk mengubah pola hidup apalagi dengan rentan waktu yang sempit. ${ }^{11,12}$ Konseling membutuhkan kemampuan yang perlu pelatihan khusus terutama dalam mengubah pola hidup pasien. Proses konseling gizi merupakan suatu strategi terapi gizi medis dan digunakan untuk pencegahan dan manajemen penyakit kronis seperti diabetes. ${ }^{10}$ Penelitian Franz dkk mengatakan bahwa konseling gizi yang tepat dan terstandarisasi terbukti dapat menurunkan kadar gula darah dan menurunkan level HbA1c hingga $2 \% .{ }^{13}$ Edukasi gizi yang tepat dapat berpengaruh terhadap perubahan pengetahuan pasien DM tipe $2,{ }^{14}$ selain itu jug dapat menurunkan indeks massa tubuh pasien dan metabolik pasien diabetes. ${ }^{15}$

Permasalahan lain yang timbul di Puskesmas Jatinangor adalah minimnya fasilitas pendukung untuk melakukan konseling. Hal tersebut diperparah dengan rendahnya kunjungan ulang yang dilakukan oleh pasien untuk melakukan konseling, akibatnya monitoring dan evaluasi hasil konseling tidak dapat dilakukan secara maksimal oleh petugas gizi puskesmas. Rendahnya kesadaran pasien akan pentingnya kunjungan ulang menjadi salah satu masalah dalam penatalaksanaan gizi. Hal ini tentunya akan menjadi hambatan bagi tenaga puskesmas dalam menanggulangi penyakit DM tipe 2 . Rendahnya kunjungan ulang pasien DM tipe 2 ke puskesmas, kemungkinan disebabkan karena kurangnya kesadaran pasien tentang pentingnya melakukan diet nutrisi yang tepat. Hal tersebut disebabkan karena petugas gizi puskesmas belum mampu memberikan motivasi kepada pasien untuk meningkatkan pengetahuan dan melakukan perubahan perilaku asupan makan yang tidak tepat. Pasien belum menyadari bahwa penyakit DM tipe 2 tidak dapat disembuhkan hanya dengan minum obat diabetes saja tetapi yang paling penting adalah melakukan diet makanan sesuai dengan kadar gula darah dan status gizi pasien. Kemungkinan yang lain mengapa pasien tidak mau melakukan kunjungan ulang adalah karena puskesmas belum mempunyai fasilitas ruang serta sarana konseling gizi yang memadai. Pasien membutuhkan tempat konsultasi yang representatif agar dia bisa mengemukakan berbagai masalah yang sedang dihadapinya. Setiap pasien memiliki masalah sendiri-sendiri, sehingga rasa kenyamanan dan privacy pasien menjadi hal yang paling dibutuhkan oleh pasien agar rahasia pribadinya dapat terjaga dengan baik.

Hambatan selama penelitian berlangsung adalah saat mencari responden dikarenakan alamat yang tersedia tidak tercantum dengan lengkap serta tidak terdapat nomor telepon pasien sehingga sulit bagi peneliti untuk melakukan pelacakan alamat responden. Keterbatasan penelitian ini adalah bahwa hasil penelitian tidak dapat digeneralisasikan. Pelayanan konseling gizi di puskesmas belum berjalan dengan baik, metode konseling yang digunakan masih konvensional serta belum didukung fasilitas yang memadai. Perlu peningkatan kapasitas tenaga dalam melakukan konseling dengan pendekatan yang tepat serta pengadaan ruangan konseling yang cukup representatif dan food model. 


\section{Daftar Pustaka}

1. Huang MC, Hsu CC, Wang HS, Shin SJ. Prospective randomized control trial to evaluate effectiveness of registered dietitianled diabetes management on glycemic and diet control in a Primary Care Setting in Taiwan. Diabetes Care. 2010;33.

2. Zeinnmaira R. Gambaran pelayanan konseling gizi bagi pasien diabetes mellitus di Klinik Gizi Puskesmas Kecamatan Duren Sawit Jakarta Timur. Universitas Islam Negeri Syarif Hidayatullah; 2012.

3. Soewondo P, Pramono LA. Prevalence, characteristics and predictors of pre-diabetis in Indonesia. Index Medicus for South-East Asia Region. 2011;20.

4. Tera BHA. Determinan ketidak patuhan diet penderita diabetes mellitus tipe 2. Diponegoro University Institutional Repository. 2011.

5. Perwira RI. Sistem untuk konsultasi menu diet bagi penderita diabetes mellitus berbasis aturan. Jurnal Teknologi. 2012;5(2):104-113.

6. Cefalu WT. Standards of medical care in Diabetes 2013. American Association Diabetes, Diabetes Care. 2015;38.

7. Funnel MM, Brown TL, Childs BP,Haas LB, Hosey GM, Jensen B, et al.National standards for diabetes self-management education. Diabetes Care. 2009;32(1):587.

8. Spahn JM, Reeves RS, Laquatra I, Kellogg M, Jortberg B, Clark NA. State of the evidence regarding behavior change theories and strategies in nutrition counseling to facilitate health and food behavior change. American Dietetic Association. 2010;110:879-891.

9. Gravel K, Legare F, Graham ID. Barriers and facilitators to implementing shared decisionmaking in clinical practice: a systematic review of health professionals' perceptions. Implement Sci.2006; 1:16.

10. Jansink R, Braspenning J, Weidjen TVD, Elwyn G, Grol R.Primary care Nurses struggle with lifestyle counseling in diabetes care: a qualitative analysis. BMC Family Practice. 2010;11:41.

11. Franz MJ, Boucher JL, Pastors JG, Powers MA. Evidence-based nutrition practice guidelines for diabetes and scope and standards of practice. American Dietetic Association. 2008;108:S52-S58.

12. Rahayu AP, Jafar N, Indriasari R. The effect of education nutrition on knowledge, attitude and blood sugar levels on diabetes mellitus type 2 patient in the work area health center Makassar. Hassanudin University. 2014.

13. Pimentel GD, Portero KC, Oliveira EP, Oliveira JL, Losinskas-Hachul AC, Souza GI, et al. Long-term nutrition education reduces several risk factors for type 2 diabetes mellitus in Brazilians with impaired glucose tolerance. Nutrition Research. 2010;30:186190. 